\title{
Repolarizációs tartalékszúkítésen alapuló új proaritmia-modell izolált tengerimalac-szívben
}

\author{
Papp Henriett' ${ }^{1}$ Sarusi Annamária', Farkas Attila², Polyák Alexandra², \\ Papp Gyula', Varró András', Farkas András
}

\begin{abstract}
'Szegedi Tudományegyetem, Általános Orvostudományi Kar, Farmakológiai és Farmakoterápiai Intézet, Szeged ${ }^{2}$ SZTE, Általános Orvostudományi Kar, II. sz. Belgyógyászati Klinika és Kardiológiai Központ, Szeged
\end{abstract}

Levelezési cím:

Dr. Farkas András, SZTE, ÁOK, II. sz. Belgyógyászati Klinika és Kardiológiai Központ, 6725 Szeged, Semmelweis utca 8. E-mail: farkas.andras@med.u-szeged.hu

Célkitűzés: A gyógyszerek proaritmiás aktivitásának vizsgálatához szükség van szenzitív és megbízható experimentális modellekre. Korábbi vizsgálatunkban a repolarizációs tartalék szűkítése izolált, Langendorff-perfundált nyúlszív-modellben rendkívüli módon érzékenyítette a szíveket a gyógyszer okozta torsades de pointes kamrai tachycardia (TdP) kialakulására. loncsatorna összetétele alapján elképzelhető, hogy a tengerimalac-szív még érzékenyebb lehet a proaritmiás hatásokra. Ezért célkitüzésünk volt megvizsgálni, vajon a repolarizációs tartalék szűkítése érzékenyíti-e a tengerimalac-szíveket a gyógyszer okozta TdP kialakulására.

Módszerek: Az $\mathrm{I}_{\mathrm{Kr}}$-káliumáramot szelektíven gátló dofetilid proaritmiás aktivitását teszteltük izolált, Langendorff-perfundált tengerimalac-szívben. A repolarizációs tartalékot $I_{\mathrm{Ks}}$ káliumáramot gátló HMR 1556-tal csökkentettük. A szíveket három csoportba soroltuk: (1) kontroll ( $n=7$ szív); (2) HMR 1556 perfúzió ( $n=6$ szív); (3) dofetilid+HMR 1556 perfúzió ( $n=7$ szív). Elsődleges végpontként meghatároztuk az aritmiák gyakoriságát, valamint megmértük a frekvencia korrigált QT-szakasz $\left(\mathrm{QT}_{\mathrm{c}}\right)$ hosszát.

Eredmények: TdP nem jelentkezett egyik csoportban sem. Dofetilid+HMR 1556 perfúzió a kamrai tachyarrhythmiák gyakoriságát szignifikánsan nem befolyásolta, de az extrém mértékủ repolarizáció nyújtás jeleként szignifikánsan megnövelte a vezetési zavarok gyakoriságát (kontroll: 0\%, HMR 1556: 0\%, dofetilid+HMR 1556: 100\%). A repolarizációs tartalék szűkítése szinergista hatással fokozta a dofetilid $\mathrm{QT}_{\mathrm{c}}$ nyújtó hatását (QT $\mathrm{C}_{\mathrm{c}}$-megnyúlás: HMR 1556: 14\%, dofetilid: 20\%, dofetilid+HMR 1556: 95\%).

Következtetések: A repolarizációs tartalék szűkítése nem érzékenyítette a Langendorff-perfundált tengerimalac-szíveket a gyógyszer okozta TdP kialakulására. Érzékeny proaritmia végpontként a szerek $\mathrm{QT}_{\mathrm{c}}$ nyújtó hatása alkalmazható a modellben, mivel a repolarizációs tartalékszükítés szinergista hatással fokozza a szer által okozott QT -megnyúlást.

Kulcsszavak: Langendorff perfundált tengerimalac-szív, proaritmia, QT-szakasz, repolarizációs tartalék, torsades de pointes

New proarrhythmia model based on reduced repolarization reserve in isolated guinea pig hearts

Aims: Specific and sensitive experimental models are needed for testing the proarrhythmic liability of newly developed drugs. Recently, we found that reduced repolarization reserve sensitized isolated, Langendorff perfused rabbit hearts to development of drug-induced torsades de pointes type ventricular tachycardia (TdP). Ion channel constitution of the guinea pig heart may make it more suitable for proarrhythmia development than the rabbit heart. Thus, aim of the present study was to investigate if reduced repolarisation reserve can sensitize guinea pig heart to development of drug-induced torsades de pointes.

Methods: The proarrhythmic activity of the selective $\mathrm{I}_{\mathrm{Kr}} \mathrm{K}^{+}$current inhibitor dofetilide was tested in Langendorff perfused, isolated guinea pig hearts. Repolarization reserve was reduced by the selective $\mathrm{I}_{\mathrm{Ks}} \mathrm{K}^{+}$current inhibitor HMR 1556 . Three groups of hearts were tested: (1) Control ( $n=7$ hearts), (2) hearts perfused with HMR 1556 ( $n=6$ hearts), (3) hearts perfused with dofetilide+HMR 1556 ( $n=7$ hearts). The incidences of arrhythmias were determined as primary endpoints. Also, the rate corrected QT $\left(\mathrm{QT}_{\mathrm{c}}\right)$ interval was measured.

Results: No TdP developed in any of the groups. Dofetilide+HMR 1556 perfusion did not influence significantly the incidence of ventricular tachycardias, but it significantly increased the incidence of conduction blocks as an indication of development of extreme repolarization prolongation. (Control: 0\%, HMR 1556: 0\%, dofetilide+HMR 1556: 100\%). Reduction of repolarization reserve synergistically increased the $\mathrm{QT}_{\mathrm{c}}$ prolonging effect of dofetilide (QT $\mathrm{C}_{\mathrm{c}}$ prolongation: HMR 1556: 14\%, dofetilide: 20\%, dofetilide+HMR 1556: 95\%)

Conclusions: Reduced repolarisation reserve did not sensitize guinea pig heart to development of drug-induced torsades de pointes. However, drug-induced $\mathrm{Q}_{\mathrm{TC}}$ prolongation can be tested as a sensitive proarrhythmia endpoint in the model, as reduced repolarization reserve synergistically increases the $Q_{T C}$ prolonging effect of the test drug.

Keywords: Langendorff perfused guinea pig heart, proarrhythmia, QT interval, repolarization reserve, torsades de pointes 


\section{Bevezetés}

Proaritmiának tekintjük a gyógyszer által okozott ritmuszavarokat, amely számos mechanizmus útján alakulhat ki. Bizonyos gyógyszerek gátolják a késői egyenirányító (delayed rectifier) $\mathrm{K}^{+}$-áram gyors komponensét $\left(\mathrm{I}_{\mathrm{Kr}}\right)$, amely a repolarizációért felelős fő áram, ezáltal sérül a repolarizáció, és életveszélyes ritmuszavarok alakulhatnak ki (1). Ilyen aritmia például a gyógyszer okozta torsades de pointes típusú kamrai tachycardia (TdP), amely korábbi in vitro kísérleteink alapján izolált, Langendorff-perfundált nyúlszív-modellben gyakran előfordul. TdP számos szer súlyos mellékhatásaként jelentkezhet (2). Gyakran az EKG QT-szakaszának megnyúlása előzi meg, ez azonban nem teljesen megbízható prediktora a TdP kialakulásának (3). Egyes antidepresszánsok, antihisztaminok, antibiotikumok, antiaritmikumok, de számos más osztályba tartozó szer is rendelkezik QT-szakaszt nyújtó hatással, és képes TdP-t okozni (4).

Repolarizációs tartalék alatt a szívizom repolarizációjáért felelős mechanizmusainak összességét értjük. Ismert, hogy egyetlen $\mathrm{K}^{+}$-csatorna gátlása még nem feltétlenül okoz olyan mértékű repolarizáció-gyengülést, hogy ez aritmiához vezethessen. Ha viszont egy időben több $\mathrm{K}^{+}$-csatorna is gátlás alá kerül, már nagy valószínűséggel alakulhatnak ki súlyos aritmiák (5). Az irodalomból ismert, hogy az $\mathrm{I}_{\mathrm{Kr}}$-áram valamilyen szerrel történő gátlása esetén a késői egyenirányító (delayed rectifier) $\mathrm{K}^{+}$-áram lassú komponense $\left(\mathrm{I}_{\mathrm{Ks}}\right)$ részben kompenzálja a repolarizáló áramban bekövetkező csökkenést, így még nem feltétlenül alakul ki aritmia (6). Repolarizációs tartalék hiányában azonban az $\mathrm{I}_{\mathrm{Kr}} \mathrm{K}^{+}$-áram gátló szerek nagy valószínúséggel ritmuszavarokat válthatnak ki (1). A repolarizációs tartalék fogalma lehetőséget ad arra, hogy a proaritmiára hajlamosító tényezőket és azok klinikai mechanizmusait együttesen vizsgálhassuk (7).

Mivel szinte minden hatástani csoportban találtak olyan gyógyszereket, amelyeknek mellékhatásaként megfigyeltek TdP-t, ezért a ma érvényes ajánlások szerint minden egyes, fejlesztés alatt álló, új gyógyszernek szükséges felmérni a proaritmiás aktivitását a klinikai használatba kerülés előtt (2). Ezért a gyógyszerek proaritmiás hatásának vizsgálatához megbízható és szenzitív experimentális modellekre van szükség. A tengerimalac a legkisebb faj, amelynek szívizmában már található működő $I_{\mathrm{kr}}$-áram, ennek tekintetében a faj hasonlít az emberre, és így megfelelő fajnak tünik kardiovaszkuláris biztonság-farmakológiai vizsgálatokhoz. Korábbi vizsgálatainkban már validáltunk egy, a repolarizációs tartalék csökkentésén alapuló in vitro perfundált nyúlszív-modellt (8), azonban néhány szempont miatt úgy gondoltuk, hogy előnyösebb lenne egy hasonló elven működő tengerimalac-modell beállítása. Az egyik és talán legfontosabb szempont a tengerimalac szívének $I_{\mathrm{Ks}} / I_{\mathrm{Kr}}$ aránya. Tengerimalacban ez az arány jóval nagyobb, mint a nyúlban és az emberben mért arány, ugyanis a tengerimalac-szívében sokkal több a funkcionális $\mathrm{I}_{\mathrm{Ks}}$-áram $(6,9)$, míg a nagyobb emlősökben alacsonyabb az $\mathrm{I}_{\mathrm{ks}}$-denzitás (1). Ez viszont azt sugallja, hogy ha tengerimalac-szívben a nyúlmodellben alkalmazott farmakológiai módszerrel, a szelektív $I_{\mathrm{Ks}}$-gátló HMR 1556-tal gátoljuk az $\mathrm{I}_{\mathrm{Ks}}$-t, akkor jelentősebb repolarizációs tartalékszükítést tudunk elérni, mint a nyúlban. Ezek alapján a repolarizációs tartalékszűkítésen alapuló tengerimalac-modell nagyon nagy érzékenységgel jelezheti az $\mathrm{I}_{\mathrm{Kr}}$-gátló vegyületek repolarizációra kifejtett hatását.

Jelen munkánkban célunk volt megvizsgálni, hogy a repolarizációs tartalék szűkítése érzékenyíti-e a tengerimalac-szíveket a gyógyszer okozta torsades de pointes típusú kamrai tachycardia kialakulására a korábbi, nyúlszívvel végzett kísérleteinkben tapasztaltakhoz hasonlóan (8).

\section{Módszerek}

\section{Kísérleti preparátum}

Kísérleteinket izolált, Langendorff-perfundált tengerimalac-szíveken végeztük. A 250-650 g tömegű nőstény tengerimalacokat thiopentállal ( 3,2 ml/állat, $\sim 470$ $\mathrm{mg} / \mathrm{kg}$ ip.) túlaltattuk; az altatószerrel együtt ip. 1000 NE Na-heparint adtunk. A szívet kimetszettük, az aortát kanüláltuk, és Langendorff perfúziós rendszerre helyeztük. A kanülön keresztül az aortát retrográd módon perfundáltuk, az EKG-t folyamatosan regisztráltuk, a koronária-áramlást 5 percenként mértük.

\section{Kísérleti protokoll}

A kísérleti protokollt az 1. ábra szemlélteti. A kísérlet elején a szíveket 20 percig csak módosított Krebs-oldattal perfundáltuk (stabilizációs időszak). Az 1. és 2. csoportban a 20. perctől kezdve a szíveket a dofetilid és a HMR 1556 oldószerével, dimetil-szulfoxiddal (DMSO), a 3. csoportban pedig $100 \mathrm{nM}$ dofetiliddel perfundáltuk. A 40. perctől kezdve a 2. és 3. csoportban a perfúziót kiegészítettük 700 nM HMR 1556-tal. A kísérlet utolsó 10 percében, a 60. perctől a perfúziós ol-

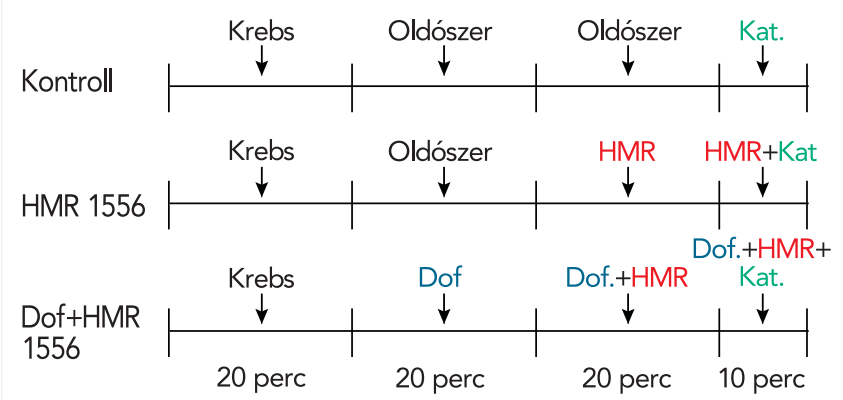

1. ÁBRA. A kísérleti protokoll a vizsgált három csoportban. Kontroll: 1. csoport. HMR 1556: 2. csoport. Dof+HMR 1556: 3. csoport. Dof.: dofetilid 100 nM. HMR: HMR 1556700 nM. Kat.: noradrenalin $100 \mathrm{nM}+$ adrenalin $25 \mathrm{nM}$ 
dat minden csoportban $100 \mathrm{nM}$ noradrenalint és $25 \mathrm{nM}$ adrenalint is tartalmazott. A szeradás kezdetétől (20. perctől) a kísérlet végéig konstans oldószer koncentrációt alkalmaztunk minden kísérletben. Az 1. csoport szolgált kontrollcsoportként. A 2. csoportban („HMR 1556" csoportban) vizsgáltuk az önmagában adott $\mathrm{I}_{\mathrm{Ks}}$-gátló HMR 1556 hatását a kísérleti végpontjainkra (QT -nyújtás, aritmiák megjelenése). A 3. csoportban („Dofetilid+HMR 1556” csoportban) vizsgáltuk, hogy az $\mathrm{I}_{\mathrm{Kr}}$-gátló dofetilid hatásait fokozza-e a szelektív $\mathrm{I}_{\mathrm{Ks}}$-gátló HMR 1556-tal történt a repolarizációs tartalék szükítése. A kísérlet utolsó 10 percében (60-70. percben) azt vizsgáltuk, hogy a katekolamin perfúzióval szimulált szimpatikus aktivitás hogyan befolyásolja az egyes szerek hatását a kísérleti végpontjainkra.

A fentiek alapján 3 csoportot vizsgáltunk (kontrollcsoport: n=7, HMR 1556 csoport: n=6, Dofetilid+HMR 1556 csoport: $n=7$ ). A kísérleteket randomizálva, vakpróbás módon végeztük.

\section{Alkalmazott szerek és oldószereik}

A dofetilid egy szelektív, III. osztályú antiaritmiás szer, potens $I_{K_{r}}$-gátló, jelentős proaritmiás hatása ismert magasabb koncentrációkban alkalmazva. $\mathrm{Az} \mathrm{I}_{\mathrm{Kr}} \mathrm{K}^{+}$-áram gátlását tekintve az $\mathrm{IC}_{50}$ értéke 10-15 nM (10). Az előkísérleteinkben tapasztaltak alapján kísérleteinkben 100 nM dofetilidet alkalmaztunk.

A HMR 1556 egy szelektív $I_{\mathrm{Ks}}$-gátló szer. $I_{50}$ értéke kb. 70-100 nM (11). Munkánkban célunk volt az $\mathrm{I}_{\mathrm{Ks}}$ szinte teljes gátlása, ezért kísérleteinkben 700 nM HMR 1556 koncentrációt alkalmaztunk.

Katekolamin perfúzió során a perfundáló oldat 25 nM adrenalint és 100 nM noradrenalint tartalmazott.

\section{EKG-analízis \\ EKG-szakaszok mérése sinusritmusban}

Előre meghatározott kísérleti időpontokban, kizárólag szabályos sinusütéseket tartalmazó 7 másodperces intervallumokban az RR-ciklusokból átlagolt EKG-jelet készítettünk. Az átlagolt EKG-jelből meghatároztuk az EKG-szakaszokat. A valós mérési időpont a pontosan megadott időponttól $\pm 0,5$ perccel térhetett el, ha ez aritmia vagy technikai okok miatt indokolt volt. Ahol az adott időpontban nem volt megfelelő számú sinusütés, az értékelésben ott hiányzó adat szerepel. Adott csoportnál, adott időpontban csak akkor ábrázoltuk az eredményeket, ha ott legalább öt kísérletben kaptunk adatot. A mérést egy kísérleten belül konzekvensen egy, a legjobb zajmentességet mutató elvezetésben végeztük.

\section{RR-intervallum korrigált QT-szakasz (QT ) számítás}

Mivel a szívfrekvencia (és az RR-intervallum) befolyásolja a QT-szakasz hosszát, megvizsgáltuk az RR- és QT-szakaszok közötti összefüggést a Krebs-perfúzió alatt. A húsz izolált Langendorff-perfundált szív mindegyikében egymás után mért 40-40 QT- és RR-szakasz összefüggését vizsgáltuk a tesztszer adása előtti utolsó percben Farkas AS és munkatársai által használt metodikát követve (12). A lineáris regresszióanalízis szignifikáns összefüggést igazolt az RR- és QT-szakaszok között $\left(\mathrm{QT}_{\mathrm{x}}=0,404 \mathrm{RR}_{\mathrm{X}-1}+39,455\right)$. Az egyenletet átalakítottuk, hogy megkapjuk a frekvenciára korrigált QT $\left(Q T_{c}\right)$ értékét 240/perc átlagos szívfrekvencia $(R R=250$ $\mathrm{ms}$ ) értékre korrigálva: $Q T_{c}=Q T_{x}-0,404\left(R R_{x-1}-250\right)$. $A z$ így kapott egyenletbe behelyettesítve az összetartozó QT- és RR-szakaszok hosszait, kiszámoltuk a QT -értékeket, majd ábrázoltuk a $\mathrm{QT}_{\mathrm{c}}$-szakasz hosszát az $\mathrm{RR}$-intervallum függvényében. A lineáris regresszió 0 meredekségü egyenest mutatott, amely igazolja, hogy a korrekció eltávolította az RR-intervallum hatását a QT -szakasz hosszára. A fenti egyenlettel kiszámítottuk a $\mathrm{QT}_{\mathrm{c}}$-értékeket minden egyes kísérlet sinusritmus alatti mérési időpontjaiban, és összehasonlítás céljából statisztikai analízist végeztünk az egyes kezelési csoportok között.

\section{Aritmiaanalízis}

A kísérletek mindhárom szakaszában külön meghatároztuk a nem TdP típusú kamrai tachycardia, a TdP és a kamrafibrilláció jelentkezési idejét és gyakoriságát, valamint meghatároztuk a vezetési blokkok gyakoriságát is. A blokkok gyakoriságának számításakor nem tettünk különbséget a különböző típusú vezetési blokkok között, egy kategóriába soroltuk az atrioventricularis (AV)-blokkokat (1., 2., 3. fokú AV-blokkokat) és a kamrai vezetési zavarokat (jobb és bal Tawara-szár-blokkot, és a nem specifikus intraventricularis blokkokat). Az EKG-értékelés minden esetben vakpróbás módon történt.

\section{Statisztikai értékelés}

A csoportok közötti aritmiák gyakoriságának összehasonlítására Fisher-féle egzakt tesztet alkalmaztunk Bonferoni-korrekcióval. Az egymástól független mintákból (csoportokból) származó minden egyéb változót Kruskall-Wallis-teszttel hasonlítottunk össze, és átlag \pm standard error formában ábrázoltuk. $p<0,05$ érték esetén tekintettük a különbségeket szignifikánsnak.

\section{Eredmények}

\section{Aritmia gyakoriságok}

Jelen kísérletsorozatunkban izolált tengerimalac-szívben TdP, valamint az ennek következményeként potenciálisan kialakuló kamrafibrilláció egyáltalán nem jelentkezett.

A protokoll 20-60. percében sem a dofetilid, sem a HMR 1556, sem a két szer együtt adva nem okozott kamrai tachycardiát. A protokoll utolsó időszakában (60-70. percben) a katekolaminok hozzáadásának hatására átmenetileg gyakorivá váltak a ritmuszavarok minden csoportban kezeléstől függetlenül. A legkomplexebb aritmia azonban csak a nem TdP típusú kamrai tachycardia volt, ennek gyakoriságát azonban sem a dofetilid, sem a HMR 1556, sem a két szer együttes al- 


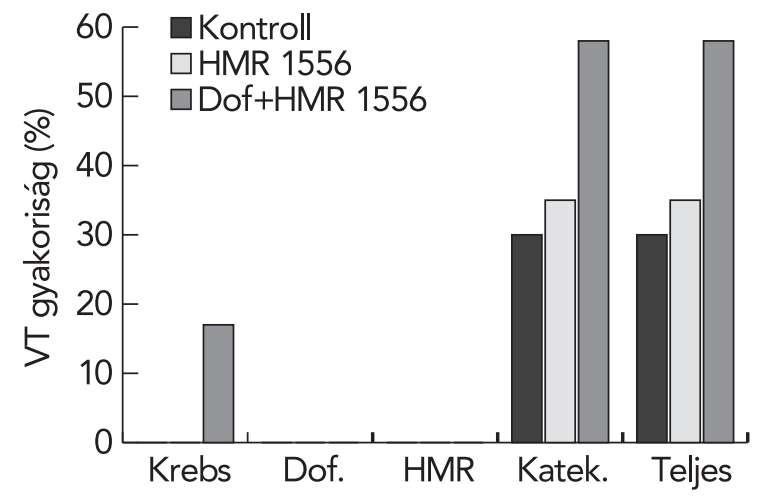

2. ÁBRA. A nem torsades de pointes típusú kamrai tachycardia (VT) felléptének gyakorisága izolált, Langendorff-perfundált tengerimalac-szívekben. Kontroll: kontrollcsoport, HMR 1556: a csak HMR 1556-tal kezelt csoport. Dof+HMR 1556: a dofetilid és HMR 1556 kombinációjával kezelt csoport. Krebs: a protokoll első 20 percében. Dof.: a protokoll 20-40. percében, HMR: a protokoll 40-60. percében. Katek.: a protokoll 60-70. percében. Teljes: a protokoll 0-70. percében

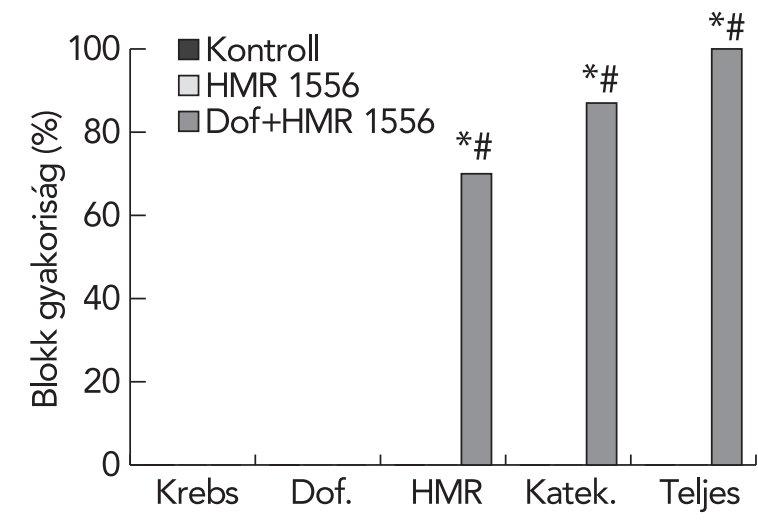

3. ÁBRA. Vezetési blokkok gyakorisága izolált Langendorff-perfundált tengerimalac-szívekben. Kontroll: kontrollcsoport, HMR 1556: a csak HMR 1556-tal kezelt csoport. Dof + HMR 1556: a dofetilid és HMR 1556 kombinációjával kezelt csoport. Krebs: a protokoll első 20 percében. Dof.: a protokoll 20-40. percében, HMR: a protokoll 40-60. percében. Katek.: a protokoll 60-70. percében. Teljes: a protokoll $0-70$. percében. ${ }^{*} p<0,05$ vs. Kontrollcsoport ${ }^{\#} p<0,05$ vs. HMR 1556 csoport

kalmazása nem növelte; a csoportok nem különböztek egymástól szignifikánsan (2. ábra).

\section{Vezetési blokkok}

Vezetési blokkok csak a kombinációs csoportban jelentkeztek. A 40. perctől kezdődően, amikor a szívek az $\mathrm{I}_{\mathrm{Kr}}$-gátló dofetilidet és az $\mathrm{I}_{\mathrm{Ks}}$-gátló HMR 1556-ot együtt kapták, szignifikánsan megnőtt a vezetési blokkok előfordulási gyakorisága (3. ábra), amely extrém mértékü repolarizáció gátlásra utal a két szer együttes adásakor. A kísérlet végén lévő 10 perces katekolamin idő- szak alatt ugyanez a hatás figyelhető meg a kombinációs csoportban (3. ábra).

\section{Frekvencia korrigált QT-szakasz (QT, )}

A csoportok között az első 20 percben (stabilizációs időszak) nem volt szignifikáns különbség a $\mathrm{QT}_{\mathrm{c}}$-paraméterben. $A z \mathrm{I}_{\mathrm{Kr}}$-gátló dofetilid már önmagában alkalmazva szinte azonnal szignifikánsan megnyújtotta a QT c-szakaszt, a szeradás első 20 perce alatt körülbelül 20\%-os QT $_{c}$-nyúlást okozott a kiindulási (19. percben mért) értékhez viszonyítva (4-5. ábra). Az I $\mathrm{I}_{\mathrm{Ks}}$-gátló HMR 1556 önmagában adva is szignifikánsan nyújtotta a $\mathrm{QT}_{\mathrm{c}}$-szakaszt (4-5. ábra). A HMR 1556 a szeradás első 20 perce alatt körülbelül 10\%-os QT-nyúlást okozott (4-5. ábra). A dofetilid és a HMR 1556 együttes adásakor masszív $\mathrm{QT}_{\mathrm{c}}$-megnyúlás jött létre, amely azt mutatja, hogy a HMR 1556 potencírozta a dofetilid $\mathrm{QT}_{\mathrm{c}}$-nyújtó hatását. A katekolaminok hozzáadása a HMR 1556 QT $_{c}$-nyújtó hatását tovább fokozta. A HMR

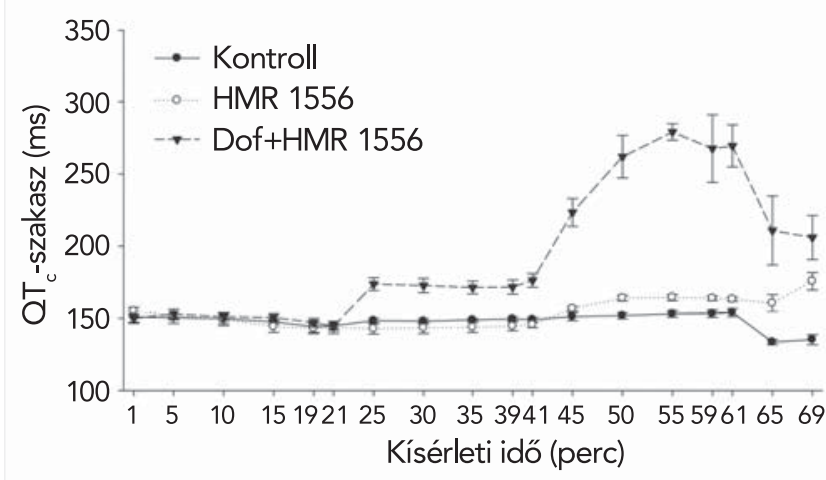

4. ÁBRA. A korrigált QT-szakasz izolált, Langendorff-perfundált tengerimalac-szívben. Kontroll: kontrollcsoport, HMR 1556: a csak HMR 1556-tal kezelt csoport. Dof+HMR 1556: a dofetilid és HMR 1556 kombinációjával kezelt csoport. ${ }^{*} p<0,05$ vs. Kontrollcsoport, \#p<0,05 vs. HMR 1556 csoport

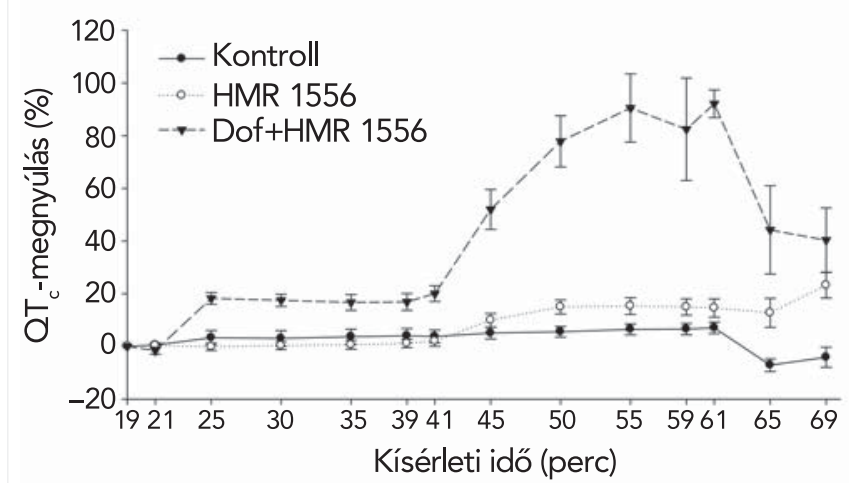

5. ÁBRA. A korrigált QT-szakasz százalékos változása izolált, Langendorff-perfundált tengerimalac-szívekben. Kontroll: kontrollcsoport, HMR 1556: a csak HMR 1556-tal kezelt csoport. Dof+HMR 1556: a dofetilid és HMR 1556 kombinációjával kezelt csoport. * $p<0,05$ vs. Kontrollcsoport, $" p<0,05$ vs. HMR 1556 csoport 
1556 és a dofetilid együttes adásakor viszont a katekolaminok által okozott $\mathrm{QT}_{\mathrm{c}}$-szakasz rövidülés ellenére is nyilvánvaló maradt a HMR 1556 potencírozó hatása, a dofetilid markánsan nyújtotta a $\mathrm{QT}_{\mathrm{c}}$-t (4-5. ábra).

\section{Megbeszélés}

Kísérleteinkben az $\mathrm{I}_{\mathrm{Kr}}$-gátló dofetilid az $\mathrm{I}_{\mathrm{Ks}}$-gátló HMR 1556-tal történt repolarizációs tartalékszúkítés ellenére sem okozott TdP-t vagy egyéb komplex aritmiát izolált, Langendorff-perfundált tengerimalac-szívben. Az aritmiák hiánya nem a szerek teljes hatástalanságának következménye, mivel a repolarizáció drasztikus módon megnyúlt a dofetilid és a HMR 1556 együttes adása mellett, amelyet direkt módon a nagyarányú $\mathrm{QT}_{\mathrm{c}}$-megnyúlás, indirekt módon pedig a vezetési zavarok nagy gyakorisággal történő megjelenése jelez. Az $I_{K s}$-gátló HMR 1556-tal történt repolarizációs tartalékszükítés szinergista módon fokozta a dofetilid $\mathrm{QT}_{\mathrm{c}}$-szakaszt nyúitó hatását. Ez arra utal, hogy az izolált tengerimalacszív-modellben az aritmiák helyett a szerek QT $T_{c}$-nyújtó hatását használhatjuk érzékeny, proaritmiás aktivitásra utaló végpontnak.

\section{Izolált tengerimalac-szív alacsony érzékenysége TdP-re}

A ma érvényes ajánlások szerint minden egyes fejlesztés alatt álló, új gyógyszernek szükséges vizsgálni a proaritmiás hatását a klinikai használatba kerülés előtt (2). A gyógyszer-biztonságossági vizsgálatban használatosak mind in vivo, mind in vitro TdP-modellek, de széles körben nem terjedtek el, mert vagy nagyon komplikáltak vagy költségesek. Ezért jelen munkánk célja volt, hogy munkacsoportunk korábbi sikeres, izolált nyúlszív-kísérleteire alapozva beállítsunk egy érzékeny, egyszerü és költséghatékony izolált tengerimalacszív-modellt, amelyben a gyógyszerek okozta TdP megjelenése direkt módon vizsgálható.

Izolált, Langendorff-perfundált nyúlszívben a dofetilidet $20 \mathrm{nM}$ feletti koncentrációban alkalmazva megfigyelhetjük a TdP megjelenését, valamint a szer szignifikáns $\mathrm{QT}_{\mathrm{c}}$-nyújtó hatását (12-14). A nyúlszívvel szemben a tengerimalac-szív érzékenysége aritmiák kialakulására nagyon alacsonynak tủnik. Eredményeink szerint a kombinált $I_{\mathrm{Kr}^{-}}$és $I_{\mathrm{Ks}_{\mathrm{s}}}$-gátlás hatására sem alakultak ki komplex aritmiák izolált tengerimalac-szívben. Ennek oka nagy valószínüséggel nem az, hogy az $\mathrm{I}_{\mathrm{Kr}}$-gátló dofetilidet vagy az $\mathrm{I}_{\mathrm{ks}}$-gátló HMR 1556-ot alacsony koncentrációban adtuk volna, mivel a két szer együttadásakor jelentősen megnyúlt a $\mathrm{QT}_{\mathrm{c}}$-szakasz hossza és nagy gyakorisággal kamrai vezetési blokkok alakultak ki, amelyek drasztikus repolarizáció gátlásra utalnak.

Michael és munkatársai in vivo pentobarbitállal altatott tengerimalac-modellen vizsgálta a TdP megjelenését. Már az előkísérleteik során szignifikáns QT-nyúlást figyeltek meg, de TdP nem jelentkezett, ezért a szereket később magasabb dózisban alkalmazták. Az $\alpha_{1}$-adrenoceptor serkentő fenilefrinnel stimulált altatott tengerimalacokban nem jelentkezett TdP, viszont az $\mathrm{I}_{\mathrm{Kr}}$ és $\mathrm{I}_{\mathrm{Ks}}$-áramok együttes gátlása szignifikáns QT-nyúlást eredményezett, és minden állatban 2:1 AV-blokk jelentkezett. Ezzel szemben, amikor adrenalinnal stimulálták a tengerimalacokat, az $\mathrm{I}_{\mathrm{Kr}}$ - és $\mathrm{I}_{\mathrm{Ks}}$-áramok együttes gátlása az állatok 75\%-ában TdP-t okozott (15). Ezek szerint lehetséges TdP-t kiváltani repolarizációs tartalékszükítéssel és katekolaminok alkalmazásával tengerimalacban is. Ezekkel az in vivo eredményekkel ellentétben a mi in vitro kísérleteinkben nem alakult ki TdP, ami arra utal, hogy valószínüleg valamilyen hormonális vagy vegetatív idegrendszeri stimulus vagy a kamrai falfeszülés hiányzott, ami in vivo körülmények között érzékenyítette volna a szíveket a TdP kialakulására. Tekintettel arra, hogy nyúlban az $I_{\mathrm{Kr}}$ - és $I_{\mathrm{Ks}}$-áramok együttes gátlása nagy gyakorisággal TdP-t okoz in vivo (3) és in vitro (8) körülmények között is, míg tengerimalacban ez a hatás csak in vivo körülmények között jelentkezik, megállapítható, hogy a tengerimalacban a TdP kialakulása sokkal jobban függ egyes, csak in vivo-ban megtalálható, eddig pontosan nem tisztázott faktoroktól.

\section{A QT_-szakasz érzékeny proaritmia biomar- ker tengerimalac-szívben, a repolarizációs tartalékszűkítés potencírozó hatása}

Az ICH S7B-ajánlás szerint a késleltetett kamrai repolarizációnak és a megnyúlt QT-szakasznak kockázatnövelő hatása van a kamrai tachyarrhythmiákra, beleértve a TdP-t is. Ez a rizikó tovább nő, ha más kockázati faktorok is társulnak mellé, például bradycardia, hypokalaemia stb. $(2,16,17)$. Az ICH S7B-ajánlás szerint humánban a QT-szakasz megnyúlása káros, ezért előírja a szerek ilyen irányú tesztelésének szükségességét azok forgalomba hozatala előtt. Az ajánlás szerint elengedhetetlen a gyógyszerek QT-szakaszt nyújtó hatását in vivo éber vagy altatott állatban vizsgálni (16). Mivel a QT-szakasz hossza függ a ciklushossztól, ezért szükséges a QT matematikai korrekciója, amely kiküszöböli a QT-szakasz szívfrekvencia-függését. Erre azonban nincs általánosan elfogadott módszer, és gyakran az alkalmazott QT korrekciós módszerek nem validáltak. Az általunk alkalmazott QT korrekciós módszer eltávolítja a QT-szakasz frekvenciafüggését izolált tengerimalac-szívben, ezért alkalmasnak tünik a gyógyszerek frekvenciától függetlenül jelentkező QT-szakaszt nyújtó hatásának vizsgálatára tengerimalac-szívben.

$\mathrm{Az}$ irodalom alapján a frekvencia korrigált QT $\left(\mathrm{QT}_{\mathrm{c}}\right)$ azonban egy elég ellentmondásos proaritmia biomarker, mert kicsi a szenzitivitása és a specificitása. Nem minden QT-nyújtó szer okoz TdP-t ugyanolyan rizikóval, és nem minden szer nyújtja a QT-szakaszt, ami TdP-t vált ki. A klinikumban sok páciens esetében regisztráltak már gyógyszer-indukált TdP-t a vártnál jóval kisebb mértékü QT-nyúlás esetén, valamint gyógyszer okozta proaritmia előfordulását leírták már normál vagy 
megrövidült QT esetén is (18). Továbbá a QT-szakasz, vagyis az akciós potenciál időtartamának megnyúlása antiaritmiás hatású is lehet, ha instabilitás, trianguláció és reverse use dependencia nem áll fenn (19).

Mivel az $I_{\mathrm{Ks}}$-gátló HMR 1556-tal történt repolarizációs tartalékszűkítés szinergista módon fokozta a dofetilid QT $T_{c}$-szakaszt nyújtó hatását, ez arra utal, hogy az alkalmazott izolált tengerimalacszív-modellben a szerek $\mathrm{QT}_{c}$-nyújtó hatását használhatjuk érzékeny, proaritmiás aktivitásra utaló végpontnak. Egy másik experimentális munkánkban szintén izolált, Langendorff perfundált tengerimalac-szívben vizsgáltuk a repolarizációs tartalék szűkités hatását $\mathrm{I}_{\mathrm{kr}}$-gátlók $\mathrm{QT}_{\mathrm{C}}$-szakasz nyújtó hatására. Abban a vizsgálatunkban viszont kifejezetten alacsony koncentrációban alkalmaztuk az $\mathrm{I}_{\mathrm{kr}}$-gátló dofetilidet és cizapriddot az $\mathrm{I}_{\mathrm{Ks}}$-gátló HMR 1556 mellett, hogy teljes mértéken elkerüljük a gyógyszer okozta ritmuszavarok keletkezését, és csak a $\mathrm{QT}_{\mathrm{c}}$-szakasz változásait tudjuk vizsgálni. Ennek ellenére a repolarizációs tartalékszükítés ugyanolyan szinergista módon fokozta az $\mathrm{I}_{\mathrm{Kr}}$-gátlók $\mathrm{QT}_{\mathrm{c}}$-nyújtó hatását, amely a modellünk nagy szenzitivitására utal (20).

Chen és munkatársainak eredményei szerint a dofetilid koncentráció-függő módon, szignifikánsan nyújtja a QT-szakasz hosszát, így a modellünk bár még validálásra vár, alkalmas lehet arra, hogy a szerek QT-szakaszt nyújtó hatását teszteljék vele (21). Tabo és munkatársai egy másik tanulmányban in vitro Langendorff-perfundált tengerimalac-szívben a késleltetett kamrai repolarizáció és a ciklushossz kapcsolatát vizsgálták a modell szenzitivitásának és megbízhatóságának tesztelése mellett. A modellt ismerten a QT-szakasz nyúlását okozó és nem okozó szerekkel tesztelték, és megállapították, hogy a modell elég szenzitív, hogy alkalmazni lehessen a szerek korai fejlesztési stádiumában a QT-intervallumot nyújtó hatás vizsgálatára (22). Ezek az eredmények megegyeznek a mi adatainkkal, de az általunk kidolgozott modell a repolarizációs tartalék $\mathrm{I}_{\mathrm{Ks}}$-blokkolással történő beszűkítése miatt azonban valószínűleg sokkal szenzitívebb lehetőséget biztosít a szerek QT-nyújtó hatásának kimutatására; az alkalmazott $\mathrm{I}_{\mathrm{Ks}}$-gátlás potencírozza a vizsgált szer QT-nyújtó hatását, ezáltal a szerek látens repolarizáció gátló hatása is kimutatható. Ennek bizonyításához azonban egy validációs vizsgálat elvégzése szükséges további referenciaszerekkel. Ennek ellenére a jelen és a korábbi vizsgálatok eredményei alapján megállapítható, hogy az in vitro Langendorff-perfundált tengerimalac-szív alkalmas a tesztelésre váró szerek QT-nyújtó hatásának vizsgálatára.

\section{Következtetések}

Az új gyógyszerek kardiovaszkuláris biztonság-farmakológiai vizsgálataiban az egyik legkeményebb végpont az aritmiák keletkezése. Jelen munkánkban bár magas koncentrációban alkalmaztuk a dofetilidet, direkt proaritmiás hatást nem láttunk. Mivel az $\mathrm{I}_{\mathrm{Ks}}$-gátlás sziner- gista módon fokozta az $\mathrm{I}_{\mathrm{kr}}$-gátló dofetilid $\mathrm{QT}_{\mathrm{c}}$-nyújtó hatását, ezért az általunk kifejlesztett, repolarizációs tartalékszűkítésen alapuló, izolált tengerimalacszívmodell mégis alkalmasnak tủnik a gyógyszerek kardiovaszkuláris biztonságosságának vizsgálatára, mert a fontos proaritmiás végpontként tekintett $\mathrm{QT}_{\mathrm{c}}$-nyújtó hatást rendkívüli érzékenységgel és költséghatékonyan képes kimutatni.

\section{Támogatók, köszönetnyilvánítás}

Munkánkat az EFOP-3.6.1-16-2016-00008, az EFOP3.6.2-16-2017-00006, NKFI -K119992 és az Emberi Erőforrások Minisztériuma UNKP-17- 4 kódszámú Új Nemzeti Kiválóság Programjának támogatásával készült.

\section{Irodalom}

1. Jost $\mathrm{N}$, Virág L, Bitay $\mathrm{M}$, et al. Restricting excessive cardiac action potential and QT prolongation: a vital role for $\mathrm{I}_{\mathrm{Ks}}$ in human ventricular muscle. Circulation 2005; 112: 1392-1399. https://doi.org/10.1161/ CIRCULATIONAHA.105.550111

2. Farkas AS, Nattel S. Minimizing repolarization-related proarrhythmic risk in drug development and clinical practice. Drugs 2010; 70 : 573-603. https://doi.org/10.2165/11535230-000000000-00000

3. Lengyel C, Varró A, Tábori K, et al. Combined pharmacological block of I(Kr) and I(Ks) increases short-term QT interval variability and provokes torsades de pointes. Br J Pharmacol 2007; 151: $941-$ 951. https://doi.org/10.1038/sj.bjp.0707297

4. Woosley RL, Black K, Heise CW, et al. CredibleMeds.org: What does it offer? Trends Cardiovasc Med 2017. https://doi.org/10.1016/j. tcm.2017.07.010

5. Roden DM. Repolarization reserve: a moving target. Circulation 2008; 118: 981-982. https://doi.org/10.1161/CIRCULATIONAHA.108.798918

6. Roden DM, Yang T. Protecting the heart against arrhythmias: potassium current physiology and repolarization reserve. Circulation 2005; 112: 1376-1378. https://doi.org/10.1161/CIRCULATIONAHA. 105.562777

7. Roden DM. Long QT syndrome: reduced repolarization reserve and the genetic link. J Intern Med 2006; 259: 59-69. https://doi.org/10.1111/j.1365-2796.2005.01589.x

8. Sarusi A, Farkas AS, Orosz S, et al. Validation of a new in vitro proarrhythmia model based on reduced repolarization reserve. Cardiovasc Res 2012; 93: S104.

9. Lu Z, Kamiya K, Opthof $\mathrm{T}$, et al. Density and kinetics of $\mathrm{I}(\mathrm{Kr})$ and I(Ks) in guinea pig and rabbit ventricular myocytes explain different efficacy of I(Ks) blockade at high heart rate in guinea pig and rabbit: implications for arrhythmogenesis in humans. Circulation 2001; 104 : 951-956. https://doi.org/ 10.1161/hc3401.093151

10. Ollerstam A, Visser SA, Duker G, et al. Comparison of the QT interval response during sinus and paced rhythm in conscious and anesthetized beagle dogs. J Pharmacol Toxicol Methods 2007; 56 : 131-144. https://doi.org/10.1016/j.vascn.2007.05.002

11. Towart R, Linders JT, Hermans AN, et al. Blockade of the I(Ks) potassium channel: an overlooked cardiovascular liability in drug safety screening? J Pharmacol Toxicol Methods 2009; 60: 1-10. https://doi.org/10.1016/j.vascn.2009.04.197

12. Farkas AS, Makra P, Csík N, et al. The role of the $\mathrm{Na}^{+} / \mathrm{Ca}^{2+}$ exchanger, I $(\mathrm{Na})$ and I (CaL) in the genesis of dofetilide-induced torsades de pointes in isolated, AV-blocked rabbit hearts. Br J Pharmacol. 2009; 156: 920-932. https://doi.org/10.1111/j.1476-5381.2008.00096.x 13. Farkas AS, Acsai K, Tóth $A$, et al. Importance of extracardiac 
alpha1-adrenoceptor stimulation in assisting dofetilide to induce torsade de pointes in rabbit hearts. Eur J Pharmacol 2006; 537: 118125. https://doi.org/10.1016/j.ejphar.2006.03.014

14. Dhein S, Perlitz F, Mohr FW. An in vitro model for assessment of drug-induced torsade de pointes arrhythmia: effects of haloperido and dofetilide on potential duration, repolarization inhomogeneities, and torsade de pointes arrhythmia. Naunyn Schmiedebergs Arch Pharmacol 2008; 378: 631-644. https://doi.org/10.1007/s00210008-0329-0

15. Michael G, Kane KA, Coker SJ. Adrenaline reveals the torsadog enic effect of combined blockade of potassium channels in anaesthetized guinea pigs. Br J Pharmacol 2008; 154: 1414-1426. https:// doi.org/10.1038/bjp.2008.169

16. ICH. International Conference on Harmonisation; guidance on S7B Nonclinical Evaluation of the Potential for Delayed Ventricular Repolarization (QT Interval Prolongation) by Human Pharmaceuticals; availability. Notice Fed Regist 2005; 70: 61133-61134.

17. Thomsen MB, Matz J, Volders PG, et al. Assessing the proarrhythmic potential of drugs: current status of models and surrogate parameters of torsades de pointes arrhythmias. Pharmacol Ther 2006 112: 150-170. https://doi.org/10.1016/j.pharmthera.2005.04.009
18. Shah RR, Hondeghem LM. Refining detection of drug-induced proarrhythmia: QT interval and TRlaD. Heart Rhythm 2005; 2: 758-772. https://doi.org/10.1016/j.hrthm.2005.03.023

19. Hondeghem LM, Carlsson L, Duker G. Instability and triangulation of the action potential predict serious proarrhythmia, but action potential duration prolongation is antiarrhythmic. Circulation 2001; 103: 2004-2013. https://doi.org/10.1161/01. CIR.103.15.2004

20. Kui $\mathrm{P}$, Orosz $\mathrm{S}$, Takács $\mathrm{H}$, et al. New in vitro model for proarrhythmia safety screening: $I_{\mathrm{KS}}$ inhibition potentiates the $\mathrm{QT}_{\mathrm{c}}$ prolonging effect of $\mathrm{I}_{\mathrm{Kr}}$ inhibitors in isolated guinea pig hearts. $\mathrm{J}$ Pharmacol Toxicol Methods 2016; 80: 26-34. https://doi.org/10.1016/j. vascn.2016.04.005

21. Cheng HC, Incardona J, McCullough B. Isolated perfused and paced guinea pig heart to test for drug-induced changes of the QT interval. J Pharmacol Toxicol Methods 2006; 54: 278-287. https:// doi.org/10.1016/j.vascn.2006.01.002

22. Tabo M, Komatsu R, Isobe $T$, et al. Accurate detection of drug-induced delayed ventricular repolarization with a suitable correction formula in Langendorff guinea pig heart. J Toxicol Sci 2010; 35: 687-698. 